\title{
To Study Prevalence of Organisms Causing Neonatal Septicemia in NICU in A Tertiary Care Hospital of Jhalawar
}

\author{
R.K Mishra ${ }^{1}$, Manish Pokra ${ }^{2}$, Rajesh Bansal ${ }^{3}$, Shilpi Hora ${ }^{4}$, Jyoti Rana ${ }^{5}$, \\ Yogendra Kumar Tiwari ${ }^{6}$ \\ ${ }^{1}$ Professor, Department of Microbiology, SMS Medical College ,Jaipur \\ ${ }^{2} \mathrm{PG} 3{ }^{\text {rd }}$ Year Resident, Department of Microbiology, Jhalawar Medical College, Jhalawar \\ ${ }^{3}$ Demonstrator, Department of Microbiology, Jhalawar Medical College, Jhalawar \\ ${ }^{4}$ Assit. Prof. Department of Microbiology, Jhalawar Medical College, Jhalawar \\ ${ }^{5}$ Demonstrator, Department of Microbiology, Jhalawar Medical College, Jhalawar \\ ${ }^{6}$ Associate Professor, Department of Microbiology, Jhalawar Medical College, Jhalawar \\ *Corresponding Author \\ Manish Pokra
}

PG $3^{\text {rd }}$ Year Resident, Department of Microbiology, Jhalawar Medical College, Jhalawar, MP, India

\begin{abstract}
Neonatal septicaemia is one of the leading causes of mortality and morbidity in developing countries like India. Incidence varies from country to country but it is much higher in developing countries than in developed nations. Reasons are not only related to good prenatal, perinatal and post natal care and the efficient antibiotic policies in developed countries, but also to the high rate of home deliveries, often overseen by unskilled attendants, in developing countries. Appropriate intervention requires an early aetiological diagnosis. Microbial aetiology of neonatal septicaemia is diverse. Several studies on neonatal sepsis have documented the diversity of bacteria. The present study reiterates the earlier findings and emphasizes the importance of periodic surveys of microbial flora encountered in particular neonatal settings to recognize the trend. The present study was conducted in Department of Microbiology and Immunology, Jhalawar Medical College, Jhalawar from March 2016 to March 2017. Clinically suspected 298 samples were included in this study.
\end{abstract}

\section{Introduction}

Neonatal mortality rate is one of the indicators for measuring the health status of a nation. There could be various reasons for neonatal mortality but septicemia continues to be a major cause of neonatal mortality and morbidity worldwide $^{(10)}$. As high as $47.5 \%-64 \%$ incidence of bacteremia has been reported in neonates previously with Gram-negative organisms such as Klebsiella being the main isolate ${ }^{(2,3)}$.

Neonatal Septicemia is one of the commonest causes of Neonatal mortality and morbidity. It is estimated that $20 \%$ of all neonates develop sepsis, and it is responsible for $30-50 \%$ of total neonatal dearth in developing countries ${ }^{(4-6)}$. Unfortunately, Sepsis is still one of the major causes of morbidity 
and mortality in neonates globally, inspite of recent advances in health care system including vaccines $^{(7)}$. Nearly $40 \%$ of under-five deaths globally occur in the neonatal period, resulting in 3.1 million newborn deaths each year ${ }^{(8)}$. The majority of these deaths usually occur in countries with low-income and almost 1 million of these deaths are attributed to infectious causes including neonatal sepsis, meningitis, and pneumonia ${ }^{(9)}$. On the other hand, the survivors of neonatal sepsis are vulnerable to short- and long-term neuro developmental morbidity ${ }^{(10-12)}$.

Neonatal sepsis is defined as a clinical syndrome in an infant of upto 28 days of life, manifested by systemic signs of infection and isolation of a bacterial pathogen from the bloodstream ${ }^{(13)}$. Sepsis is also defined as SIRS (systemic inflammatory response syndrome) resulting from a suspected or proven infection. The clinical spectrum of sepsis begins when a systemic infection (e.g.: bacteraemia, fungemia, viremia) or localized infection (e.g.: meningitis, pneumonia, pyelonephritis) progresses from sepsis to severe sepsis (the presence of sepsis combined with organ dysfunction), septic shock ( severe sepsis plus the persistence of hypo perfusion or hypotension for $>1 \mathrm{hr}$ despite adequate fluid resuscitation or a requirement for inotropic agents or vasopressors), multiple organ dysfunction syndrome (MODS), and ultimately death. ${ }^{(14)}$

According to the data from National Neonatal Perinatal Database (NNPD, 2002-03) the incidence of neonatal sepsis is 30 per 1000 live births. The database comprising 18 tertiary care neonatal units across India found sepsis to be one of the commonest causes of neonatal mortality contributing to $19 \%$ of all neonatal deaths. ${ }^{(15)}$

Prior to 1937 mortality from neonatal septicaemia was 90 per cent. After beginning of antibiotic era, the figure has fallen to $13-45 \% .{ }^{(16)}$ Mortality was significantly higher in babies with positive blood culture. $^{(17)}$

Diagnosis and management of sepsis are a great challenge facing neonatologists in NICUs. Clinical diagnosis of presentation is difficult due to nonspecific signs and symptoms. In addition, laboratory diagnosis is time consuming. This matter necessitates the initiation of empirical antibiotic therapy till the suspected sepsis is ruled out. At the same time, increased multidrug resistant organisms make the treatment options fewer and the effective treatment is delayed ${ }^{(18)}$

\section{Aims and Objectives}

1. To study the prevalence of organisms causing neonatal septicaemia in tertiary care hospital.

2. To study positivity rate of blood culture of neonates.

3. To study antimicrobial susceptibility pattern

\section{Materials and Methods}

The present study was conducted in Department of Microbiology and Immunology, Jhalawar Medical College, Jhalawar from March 2016 to March 2017.

Blood samples were collected from patients admitted in the NICU in Hira Kunwar Ba Hospital, Jhalawar. Total numbers of cases included in this study were 298 out of which 110 were culture positive.

\section{Selection criteria for Subjects Inclusion criteria}

1) Neonates of both sexes were included in this study.

2) Neonates presenting with signs and symptoms such as refusal to feed, lethargy, fever, hypothermia, vomiting, diarrhoea, abdominal distension, jaundice, respiratory distress, seizures etc., or any external evidence of sepsis like umbilical cord infection, skin infection etc. were taken up for study.

3) A sample showing the growth of organisms of low pathogenicity, a repeat blood sample was taken and on isolation of the organism on repeat culture, it was included in this study. 


\section{Exclusion criteria}

1) Neonates with absence of signs of sepsis were excluded from this study.

2) Low pathogenic organisms like CoNS, Candida spp. unless grown on repeat culture were excluded.

3) Processing in laboratory

For each neonate, one blood samples per patient were drawn under sterile conditions. All blood cultures were processed by the Microbiology Laboratory, Jhalawar medical college. Blood culture bottles, especially for neonates, were incubated for 72 hours at $37^{\circ} \mathrm{C}$ and sub cultured every other day to blood agar, Mac Conkey agar, and incubated at $37^{\circ} \mathrm{C}$ for $24-48$ hours. Isolates of bacteria were identified by standard Microbiological techniques described in Mackie and McCartney, Practical Medical Microbiology; Diagnostic microbiology. ${ }^{(19,20)}$

Antibiotic sensitivity was done on Mueller Hinton agar (M173) by using commercially available discs from HiMedia (Table 3A \& 3B). Kirby Bauer's disc diffusion method was followed as per CLSI guidelines. ${ }^{(20)}$ Discs were stored as per manufacturer's instructions and used within expiry period.

\section{Results and Conclusion}

\section{Blood culture results $(\mathrm{N}=298)$}

\begin{tabular}{|l|c|}
\hline Culture report & Number of cases \\
\hline Culture negative & $188(63.08)$ \\
\hline Culture positive & $110(36.91)$ \\
\hline Total & 298 \\
\hline
\end{tabular}

Figures in parentheses are percentages.

Table 1. shows the results of blood cultures of the clinically suspected cases of neonatal septicaemia. 188/298(63.08\%) blood cultures were sterile while 110/298(36.91\%) were positive.

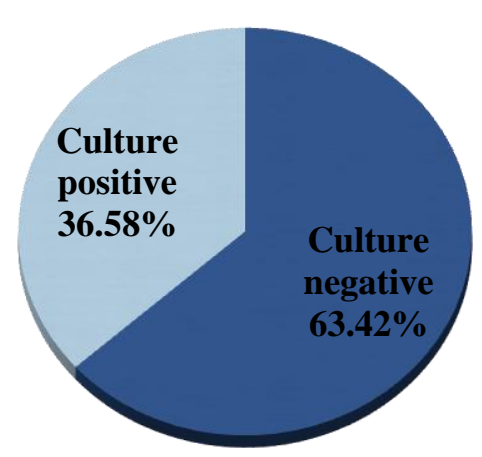

Figure 1: Blood culture results $(\mathrm{N}=298)$

\section{Organism-wise distribution $(\mathrm{N}=110)$}

\begin{tabular}{|l|c|c|}
\hline Isolates & Numbers & Percentage \\
\hline Bacterial & 76 & 69.09 \\
\hline Fungal & 34 & 30.90 \\
\hline
\end{tabular}

Culture positive cases when analysed showed growth of bacteria in 76/110(69.09\%) and fungi in 34/110(30.90\%).

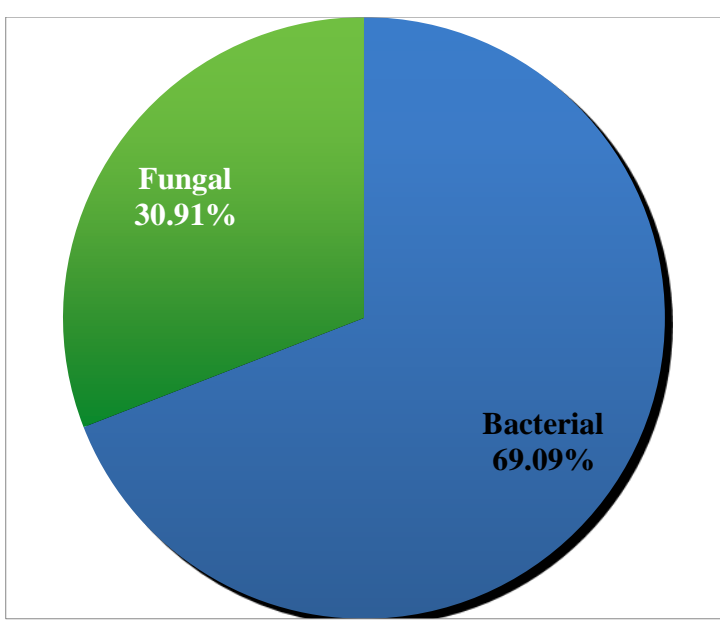

Figure 2: Organism-wise distribution $(\mathrm{N}=109)$

\section{Distribution of Gram positive isolates}

\begin{tabular}{|l|c|c|}
\hline Bacteria & Numbers & Percentage \\
\hline Staphylococcus aureus & 18 & 47.36 \\
\hline CoNS & 9 & 23.68 \\
\hline Streptococcus pyogenes & 1 & 2.63 \\
\hline Enterococcus species & 10 & 26.31 \\
\hline Total & 38 & 100 \\
\hline
\end{tabular}


Table 3. shows the distribution of various Gram positive bacteria isolated in this study. Staphylococcus aureus were 18/38 (47.36\%). Coagulase negative Staphylococcus were 9/38(23.68\%) . 10/38 (26.31\%) isolates were Enterococcus and Streptococcus pyogenes was isolated in 1/38 (2.63\%) cultures. All the Gram positive isolates were cocci and Staphylococcus aureus was found to be the dominant Gram positive organism isolated in this study.

\section{- Gram positive isolates}

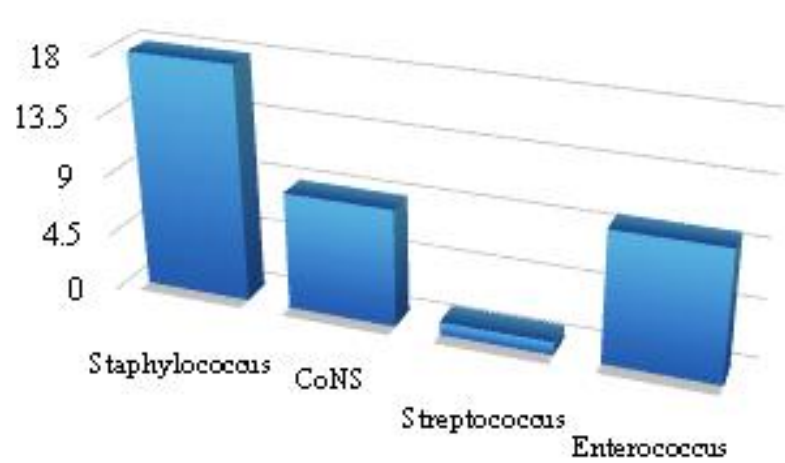

Figure 3: Distribution of Gram positive isolates

\section{Distribution of Gram negative isolates}

\begin{tabular}{|l|c|c|}
\hline Bacterial isolates & Numbers & Percentage \\
\hline Escherichia coli & 11 & 28.94 \\
\hline Klebsiella & 15 & 39.47 \\
\hline Pseudomonas species & 4 & 10.52 \\
\hline Enterobacter species & 3 & 7.89 \\
\hline Citrobacter freundii & 5 & 13.15 \\
\hline Total & 38 & 100 \\
\hline
\end{tabular}

Table 4. shows the distribution of various Gram negative bacteria isolated in this study. Klebsiella species accounted for $15 / 38$ (39.47\%) of the isolates, 11/38 (28.94\%) isolates were Escherichia coli. Pseudomonas species accounted for $4 / 38$ $(10.52 \%)$ isolates. Enterobacter species were 3/38 (7.89\%) while Citrobacter freundii accounted for $5 / 38(13.15 \%)$. All the isolates in this category were bacilli, overall Klebsiella species was the predominant Gram negative isolate observed.

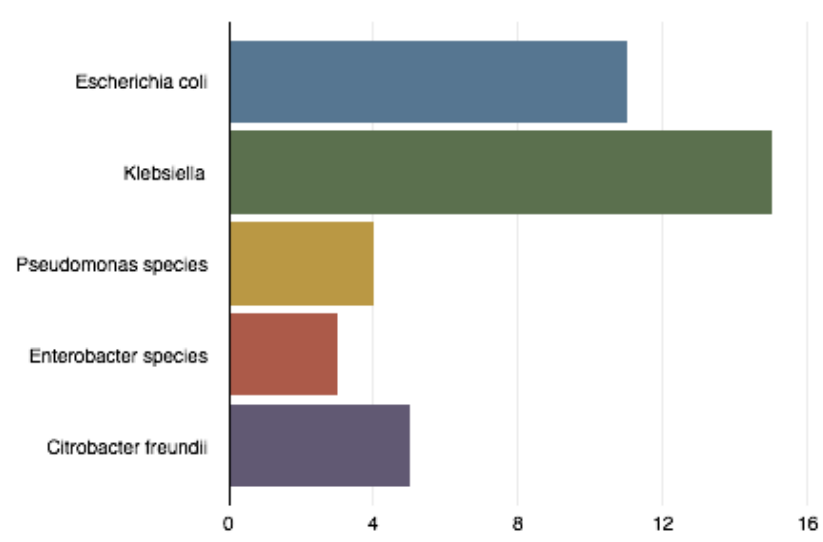

Figure 4: Distribution of Gram negative isolates

\section{Distribution of fungal isolates}

\begin{tabular}{|l|c|c|}
\hline Fungi & Numbers & Percentage \\
\hline Candida albicans & 8 & 23.52 \\
\hline Non albicans Candida species & 26 & 76.47 \\
\hline Total & 34 & 100 \\
\hline
\end{tabular}

Table 5. shows the distribution of various fungal isolates in this study. Candida albicans was isolated in $8 / 34(23.52 \%)$ and Non albicans Candida species were 26/34 (76.47\%). All the fungal isolates were yeast-like only.

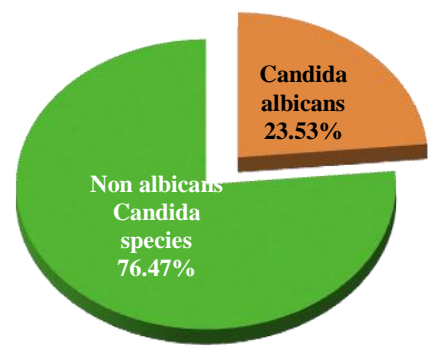

Figure 5: Distribution of fungal isolates

Staphylococcal isolates were predominantly resistant to cotrimoxazole, erythromycin, clindamycin and cefuroxime. Of all the CoNS isolated $5 / 9$ were found resistant to erthromycin and $3 / 9$ were resistant to ampicillin and clindamycin. Streptococcus pyogenes was $100 \%$ resistant to cotrimoxazole. Isolates belonging to 
Enterococcus spp. were $100 \%$ resistant to ampicillin, levofloxacin and erythromycin.

All the strains of Escherichia coli were found to be $100 \%$ resistant to cefotaxime, aztreonam, gentamicin, amikacin and levofloxacin. Of the Klebsiella spp 14/15 (92\%) isolates were resistant to amoxy-clav, cefotaxime, ceftazidime and gentamicin. Enterobacter spp. were found which showed comparable resistance pattern as that of Klebsiella spp. Almost all isolate of Citrobacter freundii was found to be resistance to all the antibiotics tested except meropenem, polymyxin $\mathrm{B}$, levofloxacin and cotrimoxazole. Among the nonfermenters, Pseudomonas spp. were found to be resistant to almost all the antibiotics except polymyxin $\mathrm{B}$.

\section{Reference}

1. Mondal GP, Raghavan M, VishnuBhat B, Srinivasan S(1991) Neonatal Septicemia Among Inborn and Outborn Babies in a Referral Hospital. Indian J Pediatr 58: 52933.

2. Roy I, Jain A, Kumar M, Agarwal SK (2002) Bacteriology of neonatal septicemia in a tertiary care Hospital of Northern India. Indian J Med Microbiol 20: 156-9.

3. Tallur SS, Kasturi AV, Nadgir SD, Krishna BVS (2000) Clinico-bacteriological sudy of neonatal septicemia in Hubli. Indian J Pediatr 67: 169-74.

4. Sankar MJ, Agarwal R, Deorari AK and Paul V K.Sepsis in the newborn. Indian Journal of Pediatrics.2008; 75(3): 261-266.

5. Vergnano S, Sharland M, Kazembe $P$, Mwansambo C, Heath PT. Neonatal sepsis: An international perspective. Arch dis child fetal neonatal ed.2005; 90(3): 220-224.

6. Kumhar GD, Ramachandran VG, Gupta P.Bacteriological analysis of blood culture isolates from neonates in a tertiary care hospital in India: Journal health population \& nutrition.2002; 20(4): 343-347.
7. Wu JH, Chen CY, Tsao PN, Hsieh WS, and Chou HS. "Neonatal sepsis: a 6-year analysis in a neonatal care unit in Taiwan," Pediatrics and Neonatology, vol. 50, no. 3, pp. 88-95, 2009. View at Publisher - View at Google Scholar · View at Scopus

8. UNICEF, WHO, The World Bank, and The United Nations, Levels and Trends in Child Mortality, UNICEF, New York, NY, USA, 2011.

9. Black RE, Cousens S, Johnson HL et al., "Global, regional, and national causes of child mortality in 2008: a systematic analysis," The Lancet, vol. 375, no. 9730, pp. 1969-1987, 2010. View at Publisher · View at Google Scholar · View at Scopus

10. Stoll BJ, Hansen N, Fanaroff AA et al., "Changes in pathogens causing early-onset sepsis in very-low-birth-weight infants," The New England Journal of Medicine, vol. 347, no. 4, pp. 240-247, 2002. View at Publisher. View at Google Scholar. View at Scopus

11. Ferreira RC, Mello RR, and Silva KS, "Neonatal sepsis as a risk factor for neuro developmental changes in preterm infants with very low birth weight," Jornal de Pediatria, vol. 90, no. 3, pp. 293-299, 2014. View at Publisher - View at Google Scholar · View at Scopus

12. Dammann O, Kuban KCK, and Leviton A, "Perinatal infection, fetal inflammatory response, white matter damage, and cognitive limitations in children born preterm," Mental Retardation and Developmental Disabilities Research Reviews, vol. 8, no. 1, pp. 46-50, 2002.View at Publisher. View at Google Scholar . View at Scopus

13. Edwards MS and Baker CJ, "Sepsis in the newborn," in Krugman's Infectious Diseases of Children, Gershon AA, Hotez PJ, and Katz SL, Eds., p. 545, Mosby, 
Philadelphia, Pa, USA, 2004. View at

Google Scholar

14. Nelson textbook of Paediatrics, $19^{\text {th }}$ ed.

Philadelphia; Saunders publication, 2012.

Thomson Press India Ltd page No.306-309

15. Tripathi S and Malik GK. Neonatal Sepsis: past, present and future; a review article. Internet Journal of Medical Update 2010 July; 5(2):45-54.

16. Sankar MJ, Agarwal R, Deorari AK, Paul VK. Sepsis in the Newborn. AIIMSNICU protocols 2008. IJP 2008; 75: 261266.

17. Gerdes SJ, Polin R. "Early diagnosis and treatment of neonatal sepsis". IJP 1998; 65: 63-78.

18. Patel SJ and Saiman L. "Antibiotic resistance in neonatal intensive care unit pathogens: mechanisms, clinical impact, and prevention including antibiotic stewardship," Clinics in Perinatology, vol. 37, no. 3, pp. 547-563, 2010. View at Publisher · View at Google Scholar · View at Scopus

19. Bhat RY, Lewis LES and Vandana KE. Bacterial isolates of early-onset neonatal sepsis and their antibiotic susceptibility pattern between 1998 and 2004: an audit from a centre in India. Italian Journal of Pediatrics 2011 $37: 32$. http://www.ijponline.net/content/37/1/32.

20. Venkataseshan S, Kumar P, Dutta S et al. Blood cultures confirmed bacterial sepsis in neonates in a north Indian tertiary care centre: changes over last decade. Jpn. J. Infect. Dis 2009, 62; 46-50. 